\title{
The Reduction of the Demand of Nicotine Due to Pregabalin and Gabapentin: Two Cases \\ ME Ceylan ${ }^{1}$, A Evrensel $^{1}$, BÖ Ünsalver ${ }^{1}$, G Cömert $^{2}$
}

\begin{abstract}
Pregabalin and gabapentin, it's pharmacological like drug are new generation antiepileptic drugs. They show their effects through voltage-gated calcium channels. Sedation and cognitive dysfunction are among their side effects. There are some investigations shows that pregabalin and gabapentin may help to quit smoking. In this article two patients are presented. One of them smoked 60 cigarettes per a day for ten years and her urge to smoke decreased after pregabalin treatment and she quitted smoking. The other one smoked 40 cigarettes per a day for 20 years and his urge to smoke decreased after gabapentin treatment and he quitted smoking. Moreover, the use of pregabalin and gabapentin in the treatment of smoking cessation is discussed through their side effects.
\end{abstract}

Keywords: Gabapentin, nicotine, pregabalin, smoking

From: ${ }^{1}$ Department of Psychiatry and Pharmacology and ${ }^{2}$ Department of Psychology, Üsküdar University, Istanbul, Turkey.

Correspondence: Dr A Evrensel, Department of Psychiatry and Pharmacology, Üsküdar University, Etiler Clinic, Nisbetiye Cad. No: 19, Besiktas Istanbul, Turkey. Fax: +902122701719, e-mail address: alperevrensel@gmail.com 


\section{INTRODUCTION}

Pregabalin and gabapentin are GABA analog. They show their effects through voltage-gated calcium channels (1). Only four studies that investigate the effect of pregabalin and gabapentin on the urge to smoke were found by searching MEDLINE (2-5). In these studies, some methodological problems such as small sample size, short duration of treatment and higher dropout rate are present. In these studies, it is found that gabapentin and pregabalin decrease the urge to smoke compared to baseline. In this article two long time smokers, one of them quits smoking after the use of gabapentin and the other one quits smoking after the use of pregabalin were presented.

\section{CASE 1}

Thirty-nine years old, college graduate, 8 years married, mother of one female patient was applied to the clinic with panic disorder symptoms. She was treated with a diagnosis of panic disorder for twelve years. Despite the fluoxetine (40 mg/day) and alprazolam (3 mg/day) treatment, she had panic attacks few times a month. Therapeutic drug monitoring (TDM) of fluoxetine and alprazolam were measured. Fluoxetine level was determined as $59.39 \mathrm{ng} / \mathrm{ml}$ (Therapeutic reference range: $120-500 \mathrm{ng} / \mathrm{ml}$ ) and alprazolam level was determined as 523.04 $\mathrm{ng} / \mathrm{ml}(5-50 \mathrm{ng} / \mathrm{ml})$ (6). According to these results fluoxetine level was evaluated very low, and alprazolam level was evaluated very high. Due to ineffective treatment, venlafaxine 75 (mg/day) and pregabalin (300 mg /day) were initiated to her. Two weeks later, TDM of venlafaxine was determined as $123.78 \mathrm{ng} / \mathrm{ml}(100-400 \mathrm{ng} / \mathrm{ml})$ and TDM of pregabalin was determined as $3.82 \mathrm{ug} / \mathrm{ml}(2-5 \mathrm{ug} / \mathrm{ml})(6)$. Although the patient smokes 60 cigarettes per a day for ten years, she claimed in the fourth month of her treatment that she had no longer urge to smoke and quitted smoking. Moreover, she said that she tried to quit smoking in the past but 
she couldn't because she likes smoking. Due to the venlafaxine and pregabalin treatment, her anxiety scores decreased from 33 to 8 . Her alprazolam ( $3 \mathrm{mg} /$ day) treatment is terminated.

\section{CASE 2}

Forty-four years old, college graduate, 10 years married, father of a child patient was admitted to the clinic for the treatment of alcohol dependence. He was hospitalized and escitalopram (20 mg/day), gabapentin (1200 mg/day) and diazepam $(15 \mathrm{mg} /$ day $)$ treatment were initiated. Two weeks later, TDM of escitalopram was determined as $33.46 \mathrm{ng} / \mathrm{ml}(15-80 \mathrm{ng} / \mathrm{ml})$ and TDM of diazepam was determined as $148.75 \mathrm{ng} / \mathrm{ml}(200-2500 \mathrm{ng} / \mathrm{ml})(6)$. Although he smokes 40 cigarettes per a day for twenty years, in the fourth month of his treatment he quitted smoking. He also currently continues to stay away from alcohol.

\section{DISCUSSION}

Nicotine stimulates the mesolimbic dopaminergic system and creates the effect of reward by increasing dopamine release in the nucleus accumbens (7). Nucleus accumbens contains GABAergic synapses (8). Vigabatrin, a new generation of antiepileptic which prevents nicotine dependent dopamine release in the nucleus accumbens of rats by inhibiting the GABA transaminase enzyme and thereby reducing the degradation of GABA reduces the level of GABA and reduces nicotine self-administration $(9,10)$. Similarly, the baclofen, $\mathrm{GABA}_{\mathrm{B}}$ receptor agonist, reduces nicotine self-administration (11). Baclofen was examined in 30 smokers for 9 weeks. In this double blind placebo controlled study, the number of daily smoking of the subjects who used baclofen was significantly lower than the placebo group (12). Positron emission tomography (PET) and limbic GABA $\mathrm{A}$ receptor levels were not high in subjects who quitted smoking. These findings show that in nicotine dependence there are 
irregularities in limbic $\mathrm{GABA}_{\mathrm{A}}$ receptor system (13). In the light of these studies, drugs which increase GABAergic transmission may be useful in the treatment of nicotine addiction. However, there are few studies which investigate drugs acting on the GABA in the treatment of nicotine addiction. In a recently published review study, new drug possibilities in the treatment of smoking cessation and the effects of glutamatergic and GABAergic systems in nicotine addiction are discussed (14). According to this study, the nicotine dependent reward system is blocked and nicotine-seeking behavior is prevented due to suppression of the glutamatergic transmission and increase of the GABAergic transmission. Authors emphasized on the effects of the glutamatergic and GABAergic drugs in the treatment of nicotine addiction.

One of the two cases presented in this paper quitted smoking after pregabalin treatment and the other one after gabapentin, it's pharmacological like drug, treatment. It is remarkable that each of the cases quitted smoking in the fourth month of their treatment. In the studies which investigate the effects of pregabalin, gabapentin and other GABAergic drugs on smoking, the duration of treatment is less than 16 weeks. Therefore in these studies the difference compared to placebo may not be detected. Placebo-controlled and double-blind studies which investigate the use of pregabalin and gabapentin in a wide sampling and observe more than 16 weeks are needed. 


\section{REFERENCES}

1. Sills GJ. The mechanisms of action of gabapentin and pregabalin. Curr Opin Pharmacol 2006; 6: 108-13.

2. White WD, Crockford D, el-Guebaly N, Patten S. A randomized, open-label pilot comparison of gabapentin and bupropion SR for smoking cessation. Nicotin Tob Res 2005; 7: 809-13.

3. Sood A, Ebbert JO, Schroeder DR, Croghan IT, Sood R, Vander Weg MW et al. Gabapentin for smoking cessation: A preliminary investigation of efficacy. Nicotine Tob Res 2007; 9: 291-8.

4. Sood A, Ebbert JO, Wyatt KD, Croghan IT, Schroeder DR, Sood R, Hays JT. Gabapentin for smoking cessation. Nicotine Tob Res 2010; 12: 300-4.

5. Herman AI, Waters AJ, McKee SA, Sofuoglu M. Effects of pregabalin on smoking behavior, withdrawal symptoms, and cognitive performance in smokers. Psychopharmacology 2012; 220: 611-7.

6. Hiemke C, Baumann P, Bergemann N, Conca A, Dietmaier O, Egberts K et al. AGNP consensus guidelines for therapeutic drug monitoring in psychiatry: update 2011. Pharmacopsychiatry $2011 ; 44:$ 195-235.

7. Olmstead TA, Sindelar JL, Easton CJ, Carroll KM. The cost-effectiveness of four treatments for marijuana dependence. Addiction 2007; 102: 1443-53.

8. Mansvelder HD, Keath JR, McGehee DS. Synaptic mechanisms underlie nicotineinduced excitability of brain reward areas. Neuron 2002; 33: 905-19.

9. Dewey SL, Brodie JD, Gerasimov M, Horan B, Gardner EL, Ashby CR Jr. A pharmacologic strategy for the treatment of nicotine addiction. Synapse 1999; 31: 7686. 
10. Paterson NE, Markou A. Increased GABA neurotransmission via administration of gamma-vinyl GABA decreased nicotine self-administration in the rat. Synapse 2002; 44: $252-53$.

11. Paterson NE, Froestl W, Markou A. The GABAB receptor agonists baclofen and CGP44532 decreased nicotine self-administration in the rat. Psychopharmacology 2004; 172: 179-86.

12. Franklin TR, Harper D, Kampman K, Kildea-McCrea S, Jens W, Lynch KG et al. The GABA B agonist baclofen reduces cigarette consumption in a preliminary doubleblind placebo-controlled smoking reduction study. Drug Alcohol Depend 2009; 103: $30-6$.

13. Stokes PR, Benecke A, Myers J, Erritzoe D, Watson BJ, Kalk N et al. History of cigarette smoking is associated with higher limbic $\mathrm{GABA}_{\mathrm{A}}$ receptor availability. Neuroimage 2013; 69: 70-7.

14. Li X, Semenova S, D'Souza MS, Stoker AK, Markou A. Involvement of glutamatergic and GABAergic systems in nicotine dependence: Implications for novel pharmacotherapies for smoking cessation. Neuropharmacology 2014; 76: 554-65. 